\title{
INFLUENCE OF THE SHADOW ECONOMY ON ECONOMIC GROWTH
}

\author{
Olga Mandroshchenko*1 Yulee Malkova ${ }^{1}$ Tatyana Tkacheva ${ }^{2}$ \\ ${ }^{1}$ Financial University under the Government of the Russian Federation, Moscow, Russia \\ ${ }^{2}$ Southwest State University, Kursk, Russia
}

Shadow economy is being paid a lot of attention in the world. This field of research is rather complex, specific and has a number of changeable characteristics. Therefore, the shadow economy has a number of problems to study. The scale and scope of the shadow economy are so that it is becoming the second one. Mean-time, it has a great potential for an ordinary economy to grow. Therefore, it is obvious that the paper is relevant from a practical point of view. The aim is to study the influence of shadow activities on economic growth and to identify devel-opment prospects based on the analysis of the existing capacity. The authors use scientific methods of research such as empirical, historical and theoretical ones (for example, literature analysis, system analysis and research, settlement and constructive analysis, vertical and hori-zontal analysis). Economical and statistical methods (comparison, summary and grouping; the method of absolute and relative values, average values) are also used in the study. The authors believe that the development of the shadow economy causes both negative and positive conse-quences for the economy and for society itself. Therefore, they should be considered when im-plementing the economic policy of the country.

Key words: Shadow economy, Economic growth, Prospects, GDP

\section{INTRODUCTION}

At present the shadow economic activity present in all countries around the world. It is in the developed rich countries and countries with transition economies, as well as in the poor countries of the Third World. Shadow tendencies in the economy have become one of the major problems in the world community.

The paper considers whether the shadow activity has a positive or negative influence on the economy and social sphere of the state. The authors try to find out if the shadow processes in the society could be a source of economic growth. It is important to clear what are the specific parameters of the "shadow economy". It is also important to reveal regularities and features of economic development and, hence, to identify and evaluate the factors stimulating economic growth.

In general, the problem has not been studied properly, so it is hardly possible to identify direction and methods of solving important social, labour and economic problems connected with the irregular sector. However, it seems impossible to create of an efficiently operating market mechanism, taking into account this irregular sector in Russia without solving these problems.

The shadow economy has been described differently in the Russian literature lately. In this re-spect, the most interesting are the works by [08], [02], [12], [10], [06] and more.

Foreign economists began studying problems of the shadow economy in 1930's. Detailed de-scriptions of a irregular sector at the macro level appeared in the scientific literature in the end of 1970's. Empirical studies of shadow activity sponsored by the International Labour
Organization and the World Bank were a kind of breakthrough. In this regard, scientific papers by [13], [15], [14] should be noted. A significant contribution to the re-search was also made by [07].

\section{RESULTS AND DISCUSSION}

Economic growth is a real wealth of any nation, so the most economic indicators depends on it. Moreover, it affects the social and political spheres and is an important element for the stability of the national economy. The problem of the economic growth is relevant and preserves scien-tific and practical significance because of the constant historical evolution, updating of regulari-ties and mechanisms of social reproduction. The value of any approaches, revealing new, un-studied aspects of the problem, are also considered. Relations of the economic growth and the "shadow economy" have hardly ever been described in this context". Although this relationship exists objectively. However, its analysis is often reduced to evaluating the "shadow economy" as an undesirable effect of the economic development process.

Numerous studies have confirmed the presence of shadow elements absolutely in all econo-mies, regardless of a state political system, its level of socio-economic development, a sector of the economy, an administrative management system and any other factors. The shadow econ-omy is a multifaceted and a fairly complicated subject for research. Although this unique phe-nomenon can be easily identified, it is impossible to measure it accurately. The study of the shadow economy phenomenon requires, first and foremost, specification of the term, the defini-tion of the meaning given to this concept by the authors. 
Russian and foreign scientists have not agreed on the specified terminology, which makes it difficult to investigate this issue. The shadow economy is referred to as "illegal", "extralegal", "underground", "criminal", "informal", "shadow", etc. This results in a terminological confusion. First, the researchers may understand the same term differently, which sometimes causes am-biguity in its interpretation. It is often determined by the researcher's field of interests (econom-ics, sociology, political science, philosophy, etc.). Second, the definitions given by the research-es are not always clear, which leads to the fact that the same activity may be given different definitions.

The analysis of domestic and foreign sources on the problems of the shadow economy has shown that all definition of the phenomenon are given to the needs of each particular study. A classification of the approaches to the definition is shown in the Table. 1.

All the points of view and approaches to the content of the shadow economy concept reflect the real processes and complement each other. All the presented approaches are more or less im-portant to understand the problem. It is necessary to agree with the integrated socio-economic approach proposed by U.N. Popov and M.Ye. Tarasov, which includes both general features and significant differences. This approach implies various groups of criteria: legal, statistical, economic, social and ethical. Therefore, we can conclude that the shadow economy is a set of relationships between individuals, groups of individuals, institutional units for the production, distribution, redistribution, exchange and consumption of material goods and services. The re-sults are not captured by the official statistics or included in the gross domestic product.

Economic growth is a phenomenon statistically measured and accounted, based on the eco-nomic indicators such as GDP and GNP; but their quantitative index is incorrect (too low) in case "the irregular sector of the economy" is excluded. The specifics of the shadow economy is that its parameters are non-fixed components of the economy. So they are not comparable with the generally accepted indicators of economic growth in volume, pace and structural shifts. Therefore it both affects the economic growth in general and emphasizes a different nature of this phenomenon In the majority of publications devoted to the discussed issue there is a list of good reasons, according to which investigating in detail, examining and assessing the shadow phenomenon is necessary.

At present, the shadow economy varies in the average range from $10 \%$ of GDP in developed countries up to $40 \%$ or more in developing countries. The data presented by the World Bank on the share of the shadow business in economies of different countries of the world is given it Table 2.

According to Table 2 a large irregular sector exists in all types of economies in developed and developing countries as well as in countries with economies in transition.

In the Russian economic system the shadow economy has been playing an important role for a long period. However, the data presented in Table 2 are based on pessimistic evaluation of the World Bank. According to this evaluation, the shadow incomes comprise $40-50 \%$ of GDP, which is 3.5 times more than in G-7 countries. Nevertheless, the authors would like to present Russian and foreign researchers' opinions on the irregular sector evaluation in Russia. According to Global Financial Interrity (GFI), the shadow economy in Russia is kept at $46 \%$ of GDP. Share evaluation of the shadow business varies in a huge range (from 20 to $70 \%$ ). Some believe that the Russian shadow economy is equal to the economic system in countries of Latin America, where its share is about $90 \%$ of GDP. Others experts give a more optimistic evaluation (20\%). Table 2 provides a comparative evaluation of the irregular sector in the Russian economy ac-cording to the World Bank and Russian Federal State Statistics Service (Rosstat).

Table 1: A classification of the approaches to the definition of the shadow economy

\begin{tabular}{|c|c|}
\hline Definition of the approach & Criterion \\
\hline A legal approach & Contempt of the law \\
\hline $\begin{array}{c}\text { Accounting and Statistics } \\
\text { an approach }\end{array}$ & Social harm (risk) \\
\hline Criminological approach & $\begin{array}{c}\text { A number of criteria are synthesized according to subjects, the main aims } \\
\text { and motives of the shadow activity, the scale of the damage caused to the } \\
\text { society, the extent of the state responsibility for the existence of the shadow } \\
\text { economy and to the nature of public attitudes towards it. }\end{array}$ \\
\hline A complex approach
\end{tabular}

Source: Compiled by the authors of the paper 
Table 2: The share of the shadow business in economies of different countries of the world in 2010-2015

\begin{tabular}{|c|c|c|c|c|c|c|c|c|c|c|c|c|c|}
\hline \multirow[b]{2}{*}{ № } & \multirow[b]{2}{*}{ Country } & \multicolumn{2}{|c|}{2010} & \multicolumn{2}{|c|}{2011} & \multicolumn{2}{|c|}{2012} & \multicolumn{2}{|c|}{2013} & \multicolumn{2}{|c|}{2014} & \multicolumn{2}{|c|}{2015} \\
\hline & & $\begin{array}{l}\text { GDP } \\
\text { bln. } \\
\text { dollars }\end{array}$ & $\begin{array}{c}\text { S.E. } \\
\%\end{array}$ & $\begin{array}{l}\text { GDP } \\
\text { bln. } \\
\text { dol- } \\
\text { lars }\end{array}$ & $\begin{array}{c}\text { S.E. } \\
\%\end{array}$ & $\begin{array}{l}\text { GDP } \\
\text { bln. } \\
\text { dollars }\end{array}$ & $\begin{array}{c}\text { S.E. } \\
\%\end{array}$ & $\begin{array}{l}\text { GDP } \\
\text { bln. } \\
\text { dollars }\end{array}$ & $\begin{array}{c}\text { S.E. } \\
\%\end{array}$ & $\begin{array}{l}\text { GDP } \\
\text { bln. } \\
\text { dollars }\end{array}$ & $\begin{array}{c}\text { S.E. } \\
\%\end{array}$ & $\begin{array}{l}\text { GDP } \\
\text { bln. } \\
\text { dollars }\end{array}$ & $\begin{array}{c}\text { S.E. } \\
\%\end{array}$ \\
\hline 1 & Russia & 1.524 & 45.3 & 2.034 & 44.5 & 2.154 & 43.6 & 2.231 & 43.0 & 2.052 & 42.4 & 1.331 & 41.7 \\
\hline 2 & USA & 14.96 & 8.8 & 15.51 & 8.7 & 16.15 & 8.6 & 16.69 & 8.5 & 17.39 & 8.5 & 18.03 & 8.4 \\
\hline 3 & Japan & 5.498 & 11.3 & 5.908 & 11.2 & 5.957 & 10.9 & 4.908 & 10.7 & 4.596 & 10.4 & 4.123 & 10.3 \\
\hline 4 & France & 2.646 & 15.1 & 2.862 & 15.0 & 2.681 & 14.9 & 2.808 & 14.8 & 2.839 & 14.8 & 2.418 & 14.7 \\
\hline 5 & China & 6.100 & 13.1 & 7.572 & 12.9 & 8.560 & 12.6 & 9.607 & 12.3 & 10.482 & 12.1 & 11.007 & 12.8 \\
\hline 6 & Turkey & 0.731 & 32.7 & 0.774 & 32.1 & 0.788 & 32.8 & 0.823 & 32.4 & 0.798 & 31.8 & 0.717 & 31.0 \\
\hline 7 & Kazakhstan & 0.148 & 42.0 & 0.192 & 41.1 & 0.207 & 40.6 & 0.236 & 39.8 & 0.221 & 38.9 & 0.184 & 38.4 \\
\hline 8 & Ukraine & 0.136 & 50.8 & 0.163 & 49.7 & 0.175 & 48.8 & 0.183 & 47.8 & 0.133 & 47.3 & 0.090 & 46.8 \\
\hline 9 & Georgia & 0.011 & 67.2 & 0.014 & 65.9 & 0.015 & 65.5 & 0.016 & 65.1 & 0.016 & 63.6 & 0.013 & 62.1 \\
\hline 10 & Thailand & 0.340 & 52.6 & 0.370 & 52.1 & 0.397 & 51.3 & 0.419 & 51.4 & 0.404 & 51.2 & 0.395 & 51.1 \\
\hline 11 & Tanzania & 0.031 & 58.3 & 0.033 & 57.6 & 0.039 & 56.8 & 0.044 & 56.4 & 0.048 & 55.4 & 0.045 & 54.8 \\
\hline 12 & Peru & 0.147 & 59.9 & 0.171 & 60.4 & 0.192 & 59.4 & 0.201 & 59.3 & 0.201 & 58.5 & 0.189 & 57.7 \\
\hline 13 & Panama & 0.028 & 64.1 & 0.034 & 64.9 & 0.039 & 65.3 & 0.044 & 64.3 & 0.049 & 62.8 & 0.052 & 61.1 \\
\hline 14 & Bolivia & 0.019 & 67.6 & 0.023 & 67.9 & 0.027 & 68.0 & 0.030 & 67.4 & 0.032 & 65.7 & 0.032 & 64.4 \\
\hline 15 & $\begin{array}{c}\text { Egypt, } \\
\text { Arab Rep. }\end{array}$ & 0.218 & 35.4 & 0.236 & 35.4 & 0.276 & 34.9 & 0.286 & 34.6 & 0.301 & 34.1 & 0.330 & 33.5 \\
\hline 16 & Morocco & 0.093 & 36.4 & 0.101 & 35.9 & 0.098 & 35.5 & 0.106 & 35.0 & 0.109 & 35.0 & 0.101 & 34.8 \\
\hline 17 & Vietnam & 0.115 & 15.6 & 0.135 & 15.6 & 0.155 & 15.4 & 0.171 & 15.4 & 0.186 & 15.2 & 0.193 & 14.8 \\
\hline 18 & Mongolia & 0.071 & 18.4 & 0.018 & 18.4 & 0.022 & 18.1 & 0.013 & 17.9 & 0.012 & 17.4 & 0.017 & 16.8 \\
\hline 19 & Switzerland & 0.581 & 8.6 & 0.696 & 8.8 & 0.665 & 8.6 & 0.684 & 8.5 & 0.702 & 8.3 & 0.670 & 8.1 \\
\hline 20 & Austria & 0.390 & 9.7 & 0.429 & 9.8 & 0.407 & 9.8 & 0.428 & 9.8 & 0.438 & 9.6 & 0.376 & 9.5 \\
\hline 21 & $\begin{array}{c}\text { United } \\
\text { Kingdom }\end{array}$ & 2.429 & 12.6 & 2.609 & 12.5 & 2.646 & 12.4 & 2.719 & 12.4 & 2.998 & 12.3 & 2.858 & 12.2 \\
\hline 22 & Netherlands & 0.836 & 13.1 & 0.893 & 13.3 & 0.828 & 13.2 & 0.866 & 13.2 & 0.879 & 13.2 & 0.750 & 13.0 \\
\hline 23 & Australia & 0.114 & 14.1 & 0.138 & 13.9 & 0.153 & 13.7 & 0.156 & 13.7 & 0.145 & 13.7 & 0.133 & 13.5 \\
\hline 24 & France & 2.646 & 15.1 & 2.862 & 15.0 & 2.681 & 14.9 & 2.808 & 14.8 & 2.839 & 14.8 & 2.418 & 14.7 \\
\hline 25 & Canada & 1.613 & 15.8 & 1.788 & 15.7 & 1.824 & 15.6 & 1.837 & 15.5 & 1.783 & 15.3 & 1.550 & 15.3 \\
\hline 26 & Germany & 3.417 & 16.1 & 3.757 & 16.3 & 3.543 & 16.1 & 3.752 & 16.0 & 3.879 & 15.6 & 3.363 & 15.3 \\
\hline
\end{tabular}

Compiled by the author based on the World Bank data http://documents.worldbank.org/curated/en/311991468037132740/pdf/WPS5356.[04] 
The irregular sector in the GDP according to the World Bank $(41-45 \%)$ and Rosstat $(21.2 \%)$ varies in a sufficiently large range in 2015 . Approximately 13 million. people are employed in the irregular sector, which represents $17-18 \%$ of the economically active population; income from the informal activities is up to 7 trillion rubles. It is a good index even in comparison with the developed countries. However, the income from activities associated with so-called black shadow economy (prostitution, pornography, drug trafficking and counterfeit goods, tax evasion, bribery and corruption) was not considered. Table 3 also shows that the growth of the economy in general is much slower than the growth of its "irregular sector".

The General Confederation of Trade Unions confirms these calculations, proves that the amount of shadow economy in Russia is $22 \%$ of GDP, and is at the level of some European countries. Besides, it suggests that the growth of the shadow economy in Russia is a consequence of the crisis in 2008-2009.

According to the report "On the informal economy" presented by the World Federation of Trade Unions (WFTU), $22 \%$ is low enough and almost equal to the index that was in the Soviet Union (about 20\%). Still, tax revenue sources and, therefore, the budget funds are considered at the federal level. When B.Yeltsin was the president of Russia, $50 \%$ of the income was distributed to the central part of the country, and $50 \%$ was distributed to the regions and local authorities. Now the money from tax revenues are shared differently: $75 \%$ are distributed to the central part of the country and $25 \%$ are kept for the local needs. ... . It is nothing more but a reaction to the tightening of competitive business environment.

Some are convinced that the shadow phenomenon causes a number of macro-economic, mi-cro-economic and social problems. L.V. Afanasyeva and T.U. Tkachev (Afanasyev, Tkachev 2015) describe a negative influence of corruption on economic growth proving that it reduces the efficiency of public investment, negatively affects the investment attractiveness, scare off foreign investors. These authors add that corruption reduces the amount of the income tax rev-enues so that the budget does not receive the necessary funds to finance state costs. Other researchers argue that the shadow economy gives a short-term positive effect on the economic policy in general. Therefore, any socio-economic phenomenon or process can have its ad-vantages and disadvantages, and the shadow economy is not an exception because its nature is also dual.

There is not one opinion whether of the shadow economy effects the economic growth positively or negatively and whether it blocks its stable growth. Different scientific schools, both domestic and foreign, have different opinions on the place of the shadow economy in the system of economic growth. Although a number of researchers suggest positive influence of the shadow economy on the economic growth in the country, most of them insist on its negative aspects. Still, the shadow economy could play a role of a certain stabilization mechanism both of national and world economy. The fact that "the shadow economy" affects GNP and GDP cannot be ar-gued at least for the reason that many of the goods produced by the "shadow economy" are not always recorded by the official statistics, but increase the country well-being.

The authors compare positive and negative aspects of the irregular sector on the formal econ-omy (Table 4).

Shadow economic phenomena significantly affect both the Russian economy system and the society. Table 4 presents the results of the comparative analysis of positive and negative aspects the irregular sector. The authors do not fully agree with a widely spread opinion that the shadow economic activity always leads to negative social and economic consequences for the state and for society as a whole. These negative consequences could also develop the formal economy depending on the shadow economy prevalence.

People are engaged in the shadow economic activities mostly for state taxation and regulation reasons. In a situation when the state "strangling" business, or has inadequate legislation, the shadow economy is necessary and inevitable is the state creates various barriers to overcome. In some ways, the irregular sector is a protective reaction of business to the disastrous actions of the state. When the state economy is developing rapidly then destabilizing factors prevail. In this case, the state is obliged to fight against the shadow economy because it undermines conditions for a fair competition and leads to a lower economic growth.

For centuries, the shadow economic processes, which originated goods-money transaction rela-tions, have been coexisting with the formal economy. At present, the shadow economy in Russia has a significant share of the country's GDP, and it has been rather beneficial for a long time.Nevertheless the Russian shadow economy produces legal products, goods and services.

The authors suggest the following to solve the problem of the shadow:

1. to identify the factors affecting the size of the shadow economy in order to define its level;

2. to express relationships between the factor and efficient features. Traditionally, the major factors in the development of the shadow economy and the criminal economic activity include the following:

- the taxation;

- excessive regulation of the economic activity;

- the formal sector takes a major part in the economy of the country.

The conducted econometric calculations have shown a correlation between the size of the in-formal sector, and the following parameters (data at a maximum rate personal income tax de-rived from the National Information Service, the data on the index of perception of corruption - from a site transparency international Russia): 
- the maximum rate of income tax (income tax);

- corruption perception index

The relation is obvious. However, it is necessary to express it with a mathematical formula, which may express a linear relationship:

$$
Y=b 0+b 1 \times 1+b 2 \times 2+E
$$

where $\mathrm{x} 1$ - a taxation rate expressed in $\%, x 2-\mathrm{CPI}$.

All the factors proved to be insignificant. The strange thing is that b1 became negative. After all, with the growth of the taxation rate the share of the shadow GDP should also grow. It is approx-imately equal to 14.7 in France and $15.3 \%$ in Canada, while the taxation rate and the CPI differ quite significantly (France - 51\%, and 7; Canada $-44 \%$, and 8.9) in France and Canada, the share of the shadow. There is another big difference between Japan and the United Kingdom. Hence, the authors come to the conclusion that there should be a nonlinear relationship or at least another explanatory factor, and maybe one and the other. Perhaps the decisive factor is the mentality of citizens, especially its national features, which could be represented as another variable. Then the authors suggest a conditional model:

$$
Y=b 0+b 1 \times 1+b 2 \times 2+b 3 \times 3
$$

where $x 3$ - a national feature of the country.

Since the state cannot guarantee ideal conditions of functioning, there is always a positive and negative influence of the state on the economy. Hence, there is a certain limit, when further re-duction of the shadow economy will negatively affect the economy of the country through the actions of the state. On the contrary, increasing the share of the shadow economy will adverse-ly affect the economy of the country through the actions of economic entities. Reduced tax rates and simplification of the regulation may not lead to a corresponding decrease in the share of the shadow economy, whereas there are countries where people got used to following the law. In-crease of the tax rate will not lead to a significant increase in the shadow economy.
Based on an analysis of the negative and positive aspects of the shadow economy, it is possible to determine the reserves of growth of the Russian economy. The shadow economy negatively affects labor productivity, but it is the shadow sector which hids the resources of the capital and labor that are not used in the legal economy. Having calculated the data on the factors of determining Russia's economic growth, as well as the average size of $20 \%$ of the shadow sector in our country (according to Rosstat), we came to the following conclusion: the reserve of growth of the economy due to the shadow sector is about $10 \%$

According to the World Bank experts, the shadow economy largely reflects the economic growth in the future, but it also limits the use of these reserves. The outflow of labor from the official sector of the economy to the "shadow economy" negatively affects the creation of efficiently operating enterprises, since it is necessary to allocate certain resources to ensure that you are not detected. It often leads to limitation of the company size, holding back its growth as well as to preventing recruitment of the staff and to implementing technological modernization.

The authors point out that the characteristics of "shadow components" in economies of various types depend on the level of economic development, the institutional environment and on the regulating role of the state. The specific content of the "shadow economy", evaluation of its role, possible methods on using or eradicating it, are also very different. For example, in developing countries the "shadow activity" is studied mainly within the framework of individual survival strategies. However, in the developed countries it is more often regarded as a factor in the ef-fective operation of large socioeconomic units (for example, transnational corporations) and is analyzed in the framework of global Capitalism.

Table 3: Comparative evaluation of the irregular sector in the Russian economy according to the World Bank and Rosstat

\begin{tabular}{|c|c|c|c|c|c|}
\hline \multirow{2}{*}{ Year } & \multirow{2}{*}{$\begin{array}{c}\text { GDP } \\
\text { bln. dollars }\end{array}$} & \multicolumn{2}{|c|}{$\begin{array}{c}\text { The shadow economy according to } \\
\text { the World Bank evaluation }\end{array}$} & \multicolumn{2}{c|}{ The shadow economy according to Rosstat } \\
\cline { 3 - 6 } & & bln. dollars &.$\%$ & bln. dollars &.$\%$ \\
\hline 2010 & 1.524 & 0.690 & 45.3 & 0.249 & 16.4 \\
\hline 2011 & 2.034 & 0.905 & 44.5 & 0.370 & 18.2 \\
\hline 2012 & 2.154 & 0.939 & 43.6 & 0.409 & 19.0 \\
\hline 2013 & 2.231 & 0.959 & 43.0 & 0.439 & 19.7 \\
\hline 2014 & 2.052 & 0.870 & 42.4 & 0.426 & 20.8 \\
\hline 2015 & 1.331 & 0.555 & 41.7 & 0.282 & 21.2 \\
\hline
\end{tabular}

Source: Compiled by the author based on statistical data 
Table 4: Comparison of positive and negative aspects of the shadow economy

\begin{tabular}{|c|c|c|}
\hline № & POSITIVE ASPECTS & NEGATIVE ASPECTS \\
\hline 1 & $\begin{array}{c}\text { The shadow business enterprises are more } \\
\text { effective than the legal ones }\end{array}$ & $\begin{array}{l}\text { The shadow economy destructively influences the regime } \\
\text { of competition, deforms the market mechanism }\end{array}$ \\
\hline 2 & $\begin{array}{l}\text { Participants of the shadow busi-ness have } \\
\text { more possibilities to increase their income }\end{array}$ & $\begin{array}{l}\text { The shadow relations distort the country tax system, do } \\
\text { not provide sufficient tax revenues to budgets of all levels }\end{array}$ \\
\hline 3 & $\begin{array}{l}\text { GDP of the country as a whole as well as the } \\
\text { GRP in the regions increase because of is the } \\
\text { shadow phenomenon }\end{array}$ & $\begin{array}{l}\text { The shadow activity negatively affects the state of public } \\
\text { finances, reduces the state budget, deforms its structure } \\
\text { and budgetary sphere }\end{array}$ \\
\hline 4 & $\begin{array}{l}\text { The shadow activity makes it possible to pre- } \\
\text { vent bankruptcy of individuals and enterprises }\end{array}$ & $\begin{array}{c}\text { The shadow processes negatively affect the monetary } \\
\text { system of the country }\end{array}$ \\
\hline 5 & $\begin{array}{l}\text { The shadow processes partially balance dif- } \\
\text { ferences in the economic development of the } \\
\text { state, when the resources between the legal } \\
\text { and shadow economies are redistributed }\end{array}$ & $\begin{array}{l}\text { The shadow activity distorts the macroeconomic } \\
\text { policy of the state }\end{array}$ \\
\hline 6 & $\begin{array}{l}\text { The shadow income is invested in industrial } \\
\text { and the financial sectors of the } \\
\text { formal economy }\end{array}$ & $\begin{array}{l}\text { The shadow economic phenomena have a negative influ- } \\
\text { ence on the industrial structure of the Russian economy, } \\
\text { economic growth and development of individual branches }\end{array}$ \\
\hline 7 & $\begin{array}{l}\text { The shadow economic activity creates addi- } \\
\text { tional workplaces and new revenue sources }\end{array}$ & $\begin{array}{l}\text { The shadow processes negatively affect the establishment } \\
\text { of the legal businesses is profitable }\end{array}$ \\
\hline 8 & $\begin{array}{c}\text { The shadow economy helps to increase } \\
\text { employment }\end{array}$ & $\begin{array}{l}\text { The shadow economic activity causes a distortion of in- } \\
\text { vestment processes }\end{array}$ \\
\hline 9 & $\begin{array}{l}\text { The shadow employment improves a financial } \\
\text { situation of all layers of the population }\end{array}$ & $\begin{array}{c}\text { The shadow economy activities create invisible barriers } \\
\text { when improving the efficiency of legal manufacturing } \\
\text { enterprises }\end{array}$ \\
\hline 10 & $\begin{array}{l}\text { The shadow relations reduce social tension } \\
\text { as well as soften undesirable social contradic- } \\
\text { tions between rich and poor }\end{array}$ & The shadow producers do not invest in R \& D \\
\hline \multirow{7}{*}{11} & \multirow{7}{*}{$\begin{array}{l}\text { The shadow activity helps to bal-ance the ex- } \\
\text { treme inequality in in-come of the population }\end{array}$} & $\begin{array}{l}\text { The shadow economy destroys the social sphere. The } \\
\text { structure of consumption is deformed as a result of unfair } \\
\text { redistribution of the income as well as expansion } \\
\text { of illegal markets }\end{array}$ \\
\hline & & $\begin{array}{l}\text { The shadow economic phenomena negatively affect re- } \\
\text { production of the labor force in the formal economy }\end{array}$ \\
\hline & & $\begin{array}{c}\text { The shadow economic activity seriously damages the } \\
\text { environment }\end{array}$ \\
\hline & & $\begin{array}{c}\text { The shadow enterprises violate the rights of consumers } \\
\text { everywhere }\end{array}$ \\
\hline & & $\begin{array}{l}\text { One of the causes of corruption in the Russian society is } \\
\text { active shadow activity }\end{array}$ \\
\hline & & $\begin{array}{l}\text { The scope of the shadow economy negatively affects the } \\
\text { process of international and domestic economic relations }\end{array}$ \\
\hline & & $\begin{array}{l}\text { The system of informal relations established in the irregu- } \\
\text { lar sector of the Russian economy, has become a stum- } \\
\text { bling block in implementing reforms }\end{array}$ \\
\hline
\end{tabular}


The authors suppose that the generally accepted approach to assess the shadow economy as a manifestation of conscious withdrawal from state control should be abandoned. They recom-mend learning how to use the shadow economy as a tool for characterizing a modern economic development.

Economic growth at the present stage is largely due to the processes of globalization of the economy in modern society. Fundamentally new factors affecting it are appearing. The main features of the globalization of the economy include:

1. The emergence of new goods and services the cost of which is not directly related to the cost of their production (often these costs approximately equal to zero). An example is the emer-gence of new technologies, such as the Internet or instant money transfer systems (SWIFT).

2. Extended market services (so that they form a part of GDP to $75 \%$ of the total).

3. The emergence of new information technologies which significantly changed the principles and mechanisms of the international markets.

4. The emergence of TNCs and the transnationalization of business (especially high-tech).

5. Strengthening the position of "personality" not only in the society, but also as a factor of pro-duction. Departments on innovations are being created in many big companies. Several dozen employees create an intellectual product that can bring hundreds of times more money to the company than it is spent on the development of the innovation.

6. Peripheralization of the economy. In most countries (especially developing countries), national enterprises and regions of specialists are being excluded from the economic development process, which do not correspond to the emerging and rapidly changing needs of the subjects that dominate the world economy today.

All this makes impossible apply old methods of calculating economic indicators but clearly shows an economic transition to a fundamentally different level called a post-industrial one. Hence, there is a need to search new methods and concepts of economic analysis and statistical accounting as well as development of a new theoretical platform based on modern economic realities. The post-industrial era which gradually involves a growing number of countries, in-troduces another dimension to the problem of economic growth. With the change of international markets and emergence of goods and services of intellectual and creative work, the formation of the information space, the mechanism for regulating economic relations is changing. Besides a criterion of maximizing profit, tasks to ensure the real fulfillment of requirements and protection of assets, maintaining confidentiality (a good example is offshore) is also added.
The official system of legislative norms, as an instrument of state power and economic policy, does not always keep up with the development of market mechanism institutions. New methods and tools for regulating economic processes appear. They are not included in the institutions of the official economy.

\section{CONCLUSIONS}

"The shadow economy" is an independent, immanent characteristic of the economy, the same as the indicators of economic growth, the level of welfare, sectoral or regional structure. It also characterizes economic development, and maybe even better than a traditional indicator of economic growth, which is used to assess the success or failure of the country's economy.

The influence of the shadow economy on economic growth is not unique, but destructive. In some cases, keeping the shadow activity out of the state control, despite the reduction in tax revenues, has a positive influence on the total state economic growth. Since any shadow activity generates legal economic one through using proceeds from the shadow activity to purchasing goods and services produced legally. As a result, the GDP increases.

The facts of the "shadow" economy growth in the modern world, which basically acts in the form of "shadow" activities of TNCs and offshore businesses, demonstrate a growing gap between real economic processes and methods of economic analysis. Today, it seems difficult to suggest constructive practical methods for recording and assessing economic activity. It could be a problem for a further research. However, the authors are confident that a struggle to increase competitiveness is not the most important means of accelerating the state economic growth. It could be the expansion of economic cooperation, which increases a number of external public goods. The fact that they are not taken into account today by statistics, does not deny a fact of their contribution to the public welfare increase.

\section{ACKNOWLEDGMENTS}

Article is executed within the state task of Southwest state university, a project code: 26.9190.2017/БЧ. 


\section{REFERENCES}

1. Afanasyeva, L., \& Tkacheva T. (2015) Use of statistical tools when monitoring threats to na-tional security, / Economic Annals-XXI (2015), 155(11-12), 36-39

2. Varvanin, A. A. (2014) the Shadow economy and economic growth http://thsp.ru/issues/issue0506/090510.htm

3. Friedrich Schneider, Andreas Buehn, Claudio E. (2008) Montenegro Shadow Economies All over the World New Estimates for 162 Countries from 1999 to $2007 \mathrm{http}: / / \mathrm{www}$.gfintegrity.org/storage/gfip/documents/reports/world_bank_shadow_economies_ all_over_the_world.pdf

4. The Shadow Economy in Europe, (2013) https:// www.atkearney.com/documents/10192/1743816/ The $\% 20$ Shadow $\% 20$ Economy $\% 20$ in $\% 20$ Europe $\% 202013 . p d f$

5. Glazyev, S. (1995) Prospects for economic growth in 1996 // the Questions of economy.. No. 5.

6. Fellow A. A., Caporaso E. A. (2006) the Shadow economy and economic growth the Bulletin of Omsk University. Series "Economy". No. 3. S. 6-7. file:/ / tenevaya-ekonomika-i-ekonomicheskiy-rost.pdf

7. Kaufmann D., Kaliberda A.(1996) Integrating the Unofficial Economy into Dynamics of Post-Socialist Economies: A framework for Analysis and Evidence // Development Discussion Paper № 558. Harvard Institute for International De-velopment. P. 81-120.

8. Latov Y. V. (2009) the Economy outside the law // essays on the theory and history of shadow economy: Moscow public scientific Fund. URL: http: //www.krugosvet.ru/ arti-cles/103/1010314/1010314a1.htm
9. Lysine O. M. Influence of shadow economic activity on the quality and pace of economic growth

10. Matsievsky N. S. (2010) the Shadow economy: analysis and evaluation // Izvestiya TPU. No. 6. URL: http://cyberleninka.ru/article/n/tenevaya-ekonomika-analiz-i-otsenki

11. Popov Yu. N. (2005). The shadow economy in the system of market economy: textbook / Yu. Popov, M. E., Tarasov, M.: a Case -240 p.

12. Peskova D. R. (2007) the Shadow economy and economic growth - identification of areas of interaction // the State policy of counteraction of corruption and the shadow economy: Mater. Vseross. scientific Conf. - M.: My "Scientific expert". P. 360-374.

13. Pyle D.J. (1989) Tax Evasion and the Black Economy. Hampshire, Macmillan.

14. Schneider F., Enste D. (2000) .Shadow Economies: Size, Causes and Consequences // Journal of Economic Literature. Vol. 38. № 1. P. 100.

15. Toffler A. (1980), The Third Wave. N.-Y., P. 222

16. Tsiklauri, V. Y., Babenko I. V. (2016) Mechanism for datenepali economy in the framework of the policy of economic security of Russia / V. Ju. Tsiklauri, I. V. Babenko// news SWSU. The Economic Series. Sociology. Management. - 2016. - - № 2. - S. 27-37.

17. ViktoriaTciklauri, Alexandra Devyatilova, Roman Artemov and Svetlana Markina Shadow Globalization as a Threat to World Economic Growth / Proceedings of the 29th International Business Information Management Association Conference Education Excellence and Innova-tion Management through Vision 2020: From Regional Development Sustainability to Global Economic Growth. 2017. P. 2478-2489 